\title{
Sustainable management of sewage sludge
}

\author{
Tymoteusz Turlej ${ }^{1, *}$, Marian Banaś ${ }^{1}$ \\ ${ }^{1}$ AGH University of Science and Technology Cracow Sciences, Department of Power Systems and \\ Environmental Protection Facilities, Mickiewicza 30, av, 30-059 Cracow, Poland
}

\begin{abstract}
The structure of municipal sewage sludge management in Poland, along with the change in legal regulations, has changed radically. The management of sewage sludge is of key importance for environmental pollution and limiting the negative impact on human health. This article presents current legal policies in Poland, methods of commonly used sewage sludge management in European countries, discusses the selection of an appropriate method for the disposal of municipal sewage sludge and an analysis of the current state of sewage sludge management in Poland. In addition, the difficulties associated with the adaptation of sewage sludge management for the requirements of sustainable development are discussed. The article contains foundations, challenges and concerns related to the thermal transformation of municipal sediments. Also forecast and directions of activities in sewage sludge management in Poland are presented.
\end{abstract}

\section{Introduction}

Municipal sewage sludge is a specific type of waste that arises in the everyday processes of life, work, leisure activities and during industrial processes. The economic growth, occurring in recent years, has caused a significant increase in the flow of generated sewage sludge, and thus caused the necessity to build or modernize sewage sludge processing plants. The main task of plants treating municipal or industrial sewage is to obtain the highest possible degree of compression. For this purpose, various types of technological processes are used, such as sedimentation processes (widely used in water and wastewater treatment) [1] or mechanical thickening (presses or centrifuges). The parameters of the sewage sludge obtained depend heavily on the technology used in the sludge treatment plant and on the type of sewage (communal or industrial).

The increase of social awareness, promotion of sustainable development and reduction of consumption of municipal fuels, caused an increase in the demand for energy from renewable sources. In comparison to traditional sources, such as oil, coal or natural gas, renewable energy is cheap and environmentally friendly. In accordance with the Energy Law from April 10, 1997. with subsequent changes (legal status as of 1 January 2011) Art. 20.2 renewable energy source has been defined as a source that uses wind, solar, geothermal (also heat pump, ground heat exchangers [2]), wave, currents and tides, river fall and energy from biomass, landfill biogas, as well as biogas generated in wastewater

\footnotetext{
* Corresponding author: turlej@agh.edu.pl
} 
discharge or treatment processes, or the decomposition of stored plant and animal remains. Renewable energy sources are, for example, solar energy, tidal energy, biomass or biofuels (production causes many unfavorable economic and social phenomena, because it causes a reduction of areas covered by forests and permanent grassland [3]).

Due to the proper calorific value, attention was paid to the possibility of using sewage sludge as a renewable fuel. This substrate can be used as a source of energy and heat in conventional and new technologies, and also as a substrate for soil fertilization and remediation if the applied technology allows to obtain a quality product.

Such re-use of sewage sludge is economically viable and environmentally friendly compared to handling waste and landfill disposal. Potential improvements in environmental protection of existing solutions include reduction of greenhouse gas emissions, improvement of soil conditions and reduction of fossil fuel consumption. The economic potential lies in the compensation costs associated with traditional waste treatment methods, reduced health costs resulting from proper treatment of waste and reduced energy costs through the use of biogas and biofuels, which can partially replace traditional fuels.

Certain legal restrictions, concerning communal sewage sludge, applied after 1.01.2016 are strongly affecting the structure of management of the sewage sludge in Poland.

\section{Legal regulations}

The legal regulations in Poland, in the field of waste management, is based on European legislation, and especially on (the so-called Sludge Directive) Directives 86/278/EEC, concerning the limitation of composting and agricultural use of waste, Directive 99/31/EC on restriction of disposal, Directive 2000/60/EC and Directive 2010/75/EC. Directive 2000/60/EC sets the norms of joint Community action in the field of Water Policy, where sludge was defined not as a waste material, but as a product from the sewage treatment process. Directive 2000/76/EC laid down the rules on the non-limitiation of incineration and co-incineration as a method of management of sewage sludge and Directive 91/271/EEC contained guidelines on limiting the effects of increasing the sludge mass. The Technical Report for End-of-Waste Criteria on Biodegradable Waste Subject to Biological treatment placed sewage sludge on the positive waste list. Poland, joining the EU structures, has committed itself to adapting Polish legislation to the legislation of the European Union. The effect of these actions is the Waste Act of 14 December 2012 (Journal of Laws of 2013, item 21) regulating the use of municipal sewage sludge. This Act and the Regulation of the Minister of Economy (Journal of Laws of 2013, item 38) introduces a complete ban on the storage of sewage sludge, which do not meet the criteria for their storage, as of 1 January 2016. This regulation is based on Landfill Directive from 1999. These criteria make practically the entire stream of municipal sewage sludge to be banned [4] (limitation of sending sewage sludge to landfills. The introduction of these legal regulations has made a significant difference in the management of sewage sludge before and after 1.01.2016.

\section{Sludge processing and management}

Technological processes used in the process of producing sewage sludge significantly depend on the type of sewage, but the most important aim is to reduce water content and volume of sediments, as well as the volume of equipment used during further processes [5]. Sewage sludge treatment process can be divided into three main phases (Fig. 1): primary treatment, secondary treatment and final management [6]. 


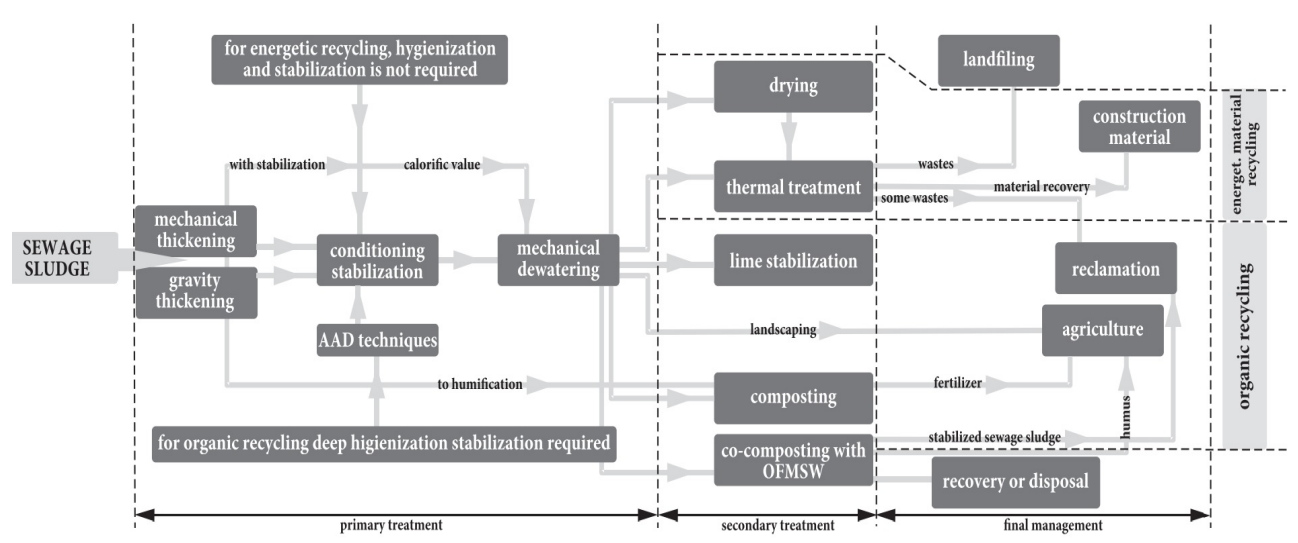

Fig. 1. The sewage sludge treatment processes at the WWTP [6].

\subsection{Primary treatment}

Wastewater treatment is done in a series of steps that can have increasing effectiveness and complexity depending on the resources available. This stage of processing sewage sludge can also be divided into several stages. The conventional sequence goes from primary (basic processes to remove suspended solid waste and reduce its biochemical oxygen demand (BOD)), secondary (biological processes to catch the dissolved organic matter missed in primary treatment), to tertiary treatment (sophisticated technology to further remove contaminants or specific pollutants). The task of the first phase of the wastewater treatment process is to drain the sludge as much as possible, and thus to reduce the volume of sewage sludge.

\subsubsection{Primary thickening}

The main aim of this phase of sewage processing is to reduce exploitation costs by reducing the volume of sludge. In order to obtain an appropriate degree of sludge thickening, we use various types of methods, e.g. gravitional methods, flotation or in compactors. Gravitional compaction is performed by using settlers (primary and secondary settlers). The use of multiflux fillings can improve the sedimentation rate [7]. However, in this case, the use of classical theory motion of suspension mechanics is very difficult, so it is more convenient to use another theories, for example, fractal theory (different kind of suspensions) [8]. Occasionally, it is necessary to disturb the sedimenting structure of the sediment to release water trapped in interstitials of these sediments (using bar stirrers) [9]. In case of a difficultsedimenting sludge the mechanical compaction processes are recommended [10].

\subsubsection{Stabilization, dewatering and higenization}

Stabilization processes are performed in fermentation reactors or in fermentation chambers. To decrease the number of pathogenic organisms and decrease the high level of organic substance, biological or chemical methods should be used. High temperature can also be used. Most commonly used processes are: methane fermentation and oxygen stabilization. Dewatering process is done by mechanical equipment: filtration press (membrane chamber) or centrifuges press [11]. Higenization can done by pasteurization, thermal drying, composting, calcination or gamma radiation. These methods can be divided as follows: thermal, biological, chemical and radiation. 


\subsection{Secondary treatment}

The second stage of processing of sewage sludge deals with compacted and stabilized sewage sludge (in the case of organic matter also deep higienization stabilization is required) [3]. Due to the way the final product is used, we can distinguish organic recycling (lime stabilization, composting) and recycling of energy and material (drying, thermal methods, natural use).

\subsubsection{Drying}

The drying process allows to obtain a product of decreased weight and volume, with specific parameters (increase in calorific by decreasing water content in sediments). Drying does not change the chemical properties and suitability for use in agriculture (fertilizers). Obtained product can be burned at incineration plants. The drying process is carried out with convection, radiation or contact drying. These processes can be performed using revolving, chamber, fluidal, line drum centrifuges.

\subsubsection{Thermal methods}

In recent years, thermal methods have been assessed as the most advantageous way to utilize sewage sludge. This is particularly related to economic and energy criteria and due to legal restrictions. Most commonly thermal methods used to neutralize sewage sludge are: burning, pyrolysis, plasma or combination of these methods. Each of these methods is composed of different basic processes, e.g. drying or degassing in case of burning in grate ovens. The choice of technology used for thermal discharges of sewage sludge is often dictated by economic, technical or environmental factors. the criteria for the differenting of thermal methods are: temperature and the excess air ratio. With the increasing coefficient of excess air we have to do with processes: pyrolysis $(\lambda=0$-carburization), pyrolysis in combination with oxidation ( $\lambda<1$ gasification), oxidation + pyrolysis $(\lambda>0$-combustion). Currently, there is a tendency in Poland to increase, as much as possible, the share of thermal methods in the process of sewage sludge disposal.

\subsubsection{Natural use}

If the parameters of sewage sludge meet the standards provided for in the legislation, sewage sludge can be used in nature and agriculture. This particularly applies to agriculture (crop production), crop cultivation for the production of compost, land reclamation, including agricultural land, for feed production. This concerns sediments that are stabilized and properly prepared, e.g. biological, chemical or thermal treatment. Sewage sludge contains multiple compounds having agriculture values, including organic matter, nitrogen, phosphorus and potassium compounds and, to a lesser extent, calcium, sulphur and magnesium compounds and for that reason an addition of sewage sludge to land increases organic matter in the soil (the improved physical properties of soil and high levels of organic matter can enhance biological properties in the soil, including improvement of enzymatic, microbial and earthworm activities [12]. However, it is important to remember the limits of the specific heavy metals (cadmium, copper, nickel, lead, zinc, mercury, chromium) described in the Directives 86/278/EEC. 


\section{Management of sewage sludge in Poland and in other European countries}

Depending on the form and quality of sewage sludge, there are several ways of dealing with this kind of waste, e.g. organic recycling, mineral recycling, recovery in composting plants, biogas plants and cement plants, or disposal using thermal methods in incineration plants and co-incineration plants. Of course, it is possible to store municipal sewage sludge, but given the stringent criteria for storing, the storage of this waste without prior processing is in practice impossible. The choice of a specific method of municipal sewage sludge management depends on the legal conditions that have significantly influenced the structure of municipal sewage sludge over recent years

\subsection{Management strategies of sewage sludge in European countries}

In the European Union, Germany is the highest sludge producer; ; they produce about $2,200,000$ tons of DM annually (Fig. 2). Degree of connection to the sewage network is almost $97 \%$, share of thermal methods is above 52\%, and sewage sludge is not stored [14]. In countries like Denmark, Spain, France or Ireland the amount of sludge used for agriculture is more then $50 \%$, but in Greece, Netherlands, Romania or Slovakia sludge is not used in agriculture.

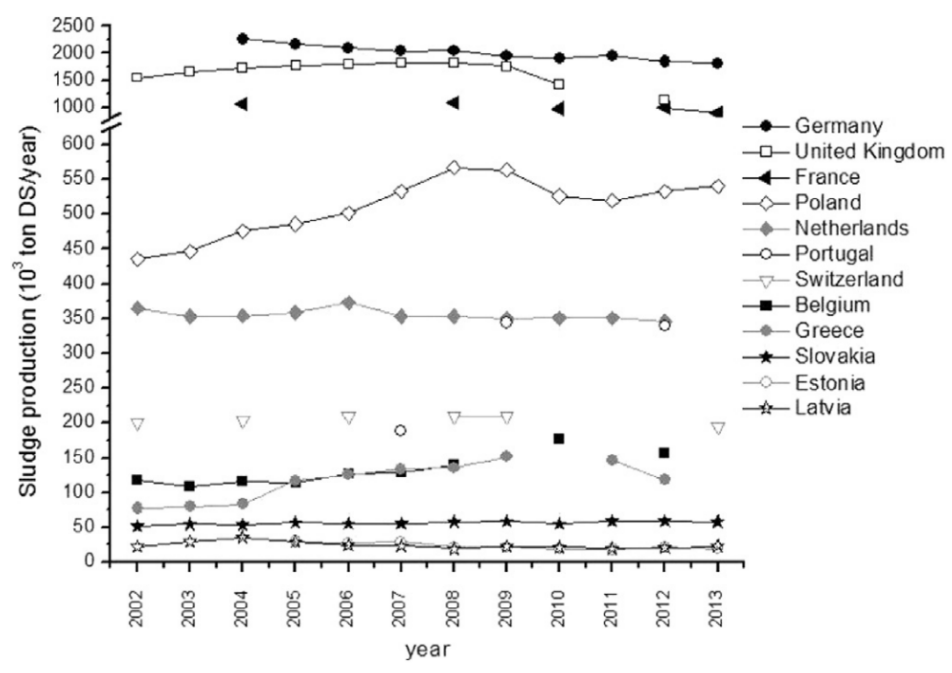

Fig. 2. The production of sewage sludge in selected countries of EU [13].

In non-EU countries larger amounts of sludge are applied in agriculture (Switzerland and Norway). The policy of using sewage sludge in agriculture depends on the country's decision, e.g. Switzerland has banned the use of biosolids on farmland, but Norway were recycled above $80 \%$ of biosolids to farmlands or for economic reasons: it is estimated that the average costs of different wastewater treatment and disposal of non-treated sludge is 160-210 EUR/tonnes DM and in case of use of dewatered sludge in agriculture or forestry including incineration with household waste or reclamation of degraded areas, costs increase to about 210-300 EUR/tonnes DM (Tab. 1). However, not only economic and energy criteria are the most important, there is the Best Practicable Environmental Options (BPEO) as an approach, which reduces environmental pollution and damage and makes improvements in the quality of the environment. 
Table 1. Average cost of different strategies of management of sewage sludge in European countries [15].

\begin{tabular}{|c|c|}
\hline Methods of utilization & Cost (EURO)/t DM) \\
\hline Agriculture; Raw sludge; Partly dewatered sludge (15-25\% DS) & 160 \\
\hline Dry sludge & 210 \\
\hline Forestry & 240 \\
\hline Composting & 310 \\
\hline Incineration & 315 \\
\hline Reclamation of landfills and degraded areas; Landfill & 255 \\
\hline
\end{tabular}

This approach allows for a selection of a direction for sludge treatment and disposal that will minimize the overall potentially adverse environmental impacts, on a case-by-case basis with costs having a secondary role [16]. Agricultural use of sewage sludge is usually considered as the BPEO, but it requires specific analysis of sludge and is dependent on many external factors and also many countries restrict the use of sewage sludge for food production due to potential risk of pathogens and transmission of contaminations [17]. Based on the statement that there is no universal technological solution which will consider local issues and sustainable development [18], it is difficult to develop clear guideline for management of sewage sludge in accordance with the rules of sustainable development. However, sustainable development should maximize the sludge recovery (or recycle) benefits through renewable energy systems. Development of the innovative technologies and managements systems should be appropriate to local conditions.

\subsection{Current situation of the management of sludge sewage in Poland}

Poland is at the forefront of European countries in terms of production of sewage sludge (Fig. 2).

Table 2. Characteristics of incinerators OF MMS operated in Poland [19].

\begin{tabular}{|c|l|c|}
\hline Lp. & \multicolumn{1}{|c|}{ Location } & $\begin{array}{c}\text { Nominal productivity } \\
\text { [thous. Mg d.m./year] }\end{array}$ \\
\hline 1 & Warsaw - Sewage Sludge Treatment Plant (SSTP) „Czajka” & 62.2 \\
\hline 2 & Cracow - SSTP „Płaszów” & 23.0 \\
\hline 3 & Łódź- SSTP & 21.0 \\
\hline 4 & Gdańsk - SSTP „Wschód” & 14.0 \\
\hline 5 & Gdynia - SSTP „Dębogórze” & 9.0 \\
\hline 6 & Bydgoszcz - SSTP „Fordon” & 7.8 \\
\hline 7 & Szczecin - SSTP „Pomorzany” & 6.0 \\
\hline 8 & Zielona Góra - SSTP „Lącza” & 6.4 \\
\hline 9 & Kielce - SSTP „Sitkówka” & 6.2 \\
\hline 10 & Olsztyn - SSTP „Łyna” & 3.2 \\
\hline 11 & Łomża - Łomżyńska SSTP & 1.5 \\
\hline & total & 160.3 \\
\hline
\end{tabular}

Poland, together with 4 other countries, produces $75 \%$ of total sewage sludge production in the European Union, but still the main methods of sewage sludge management remain agricultural use and incineration. In Poland, due to legal restrictions, 
a significant decrease in the use of sewage sludge in land reclamation and landfills is noticeable. Much of the scientific work in this area strongly underlines the importance of using thermal methods as a way of managing municipal sewage sludge [19]. Promoting the thermal methods of sewage sludge processing has resulted in an increase in the number of mono-incinerators (Tab. 2). However, the numerous operational problems of these plants have resulted in a decrease in actual capacity - only 50\% of the nominal capacity of these plants. there was a huge disproportion between Poland and other European countries several years ago. Particularly noticeable was the difference in the degree of connection to the sewage system and the percentage of the method of thermal management of sewage sludge. Compared to the countries which joined to the EU in 2004 (EU12), Poland is definitely ahead of those countries in this area.

\section{Forecast and directions of activities in sewage sludge management in poland}

There has been only a slight increase in the amount of waste generated from this group in 2010-2013. At the same time, there was an increase in the amount of treated wastewater from $97.6 \%$ in $2011,97.8 \%$ in 2012 , up to $99.8 \%$ in 2013 and finally the amount of treated wastewater amounted to $99.3 \%$ in 2014 [20]. Taking into account the observed trends in the production of the communal sewage sludge in 2011-2014 (increase of $\approx 6 \%$ ) and the dynamic development of sewage and water supply networks leading to the formation of an increased amount of the sewage sludge, for the purpose of forecasting, it was assumed that each year the amount of sewage sludge per dry matter will increase about $2 \div 3 \%$. In connection with the planned establishment of protection areas of water reservoirs inland waterway in the mode of art. 60 of the Act of 18 July 2001 - Water Law, in these areas there is an increase in the amount of municipal sewage sludge requiring development in a different way than through their use in agriculture or land reclamation. In the field of management of sewage sludge, it is necessary to strive to completely reduce the storage of sewage sludge, increase the amount of processed sewage sludge before introducing it into the environment and the amount of sewage sludge subjected to thermal utilization. It is necessary to maximize the degree of use of biogenic substances contained in the sediments, while meeting all the requirements regarding sanitary, chemical and environmental safety.

\section{Conclusion}

In accordance with the principles of the closed-circular economy, sustainable development in sewage sludge management should primarily be based on recovery and, subsequently, on disposal. This particularly applies to the use of by-products generated in the process of processing sewage sludge: organic matter, carbon, phosphorus, nitrogen or volatile acids. This type of material is great for agricultural purposes (granulates, fertilizers, compost) and natural use(after removal of, for example, heavy metals). Compost obtained from sewage sludge processing can be used for soil preservation or recultivation of degraded areas. The materials obtained for the treatment of sewage sludge are a valuable resource, for example the recycling of phosphorus, which is a rare resource. In addition, in the area of reduction of greenhouse gas emissions, use of fossil fuels, it is proposed to use sewage sludge for the cultivation of energy crops. In case sewage sludge does not meet the requirements specified in the legislation of a given country, the most economical way of utilization is the thermal methods (incineration, co-incineration). The selection of an appropriate strategy for the management of municipal sewage sludge should take into account all environmental and economic factors, and should include an analysis of the final products market, the size 
of a given market and determine the time to implement a given solution. Due to legal restrictions in Poland, the most popular methods are thermal waste disposal. The infrastructure developed in recent years for the thermal treatment of sewage sludge has definitely increased the share of thermal methods. Recent years of vast improvement of the state of water and sewage management have resulted in a significant improvement in the state of sewage sludge management in Poland.

\section{References}

1. K. Kołodziejczyk, Przemysł Chemiczny, 96, 1687-1690 (2017)

2. J. Wołoszyn, A. Gołaś, J. Sustain. Dev. Energy Water Environ. Syst. 5, 645-656 (2017)

3. S. Różycki, Przemysł Chemiczny, 96, 1716-1618 (2017)

4. M. Cyranka, M. Jurczyk, T. Pająk, 1st International Conference on the sustainable energy and environment development (SEED), 10 (2016)

5. I. Cywiński, S. Gdula E. Kempa, J. Kurbiel, H. Płoszański, Oczyszczanie ścieków miejskich, Arkady (1972)

6. A. Wójtowicz, Modelowe rozwiąania w gospodarce osadowej, Bydgoski Dom Wydawniczy" Margrafsen" (2013)

7. K. Kołodziejczyk, Arch. Min. Sci. 61, 59-68 (2016)

8. B. Hilger, M. Banaś, K. Kołodziejczyk, E. Wisla-Walsh, P. Warzecha, SGEM2016: 16th International multidisciplinary Scientific Geoconference, 227-234 (2016)

9. J. Podedworna, K. Umiejewska, Technologia osadów ściekowych, Oficyna Wydawnicza $P W(2008)$

10. J. Bień, T. Pająk, K. Wystalska, Unieszkodliwiania komunalnych osadów ściekowych, Wydawnictwo Politechniki Częstochowskiej (2014)

11. J. Bień, K. Wystalska, Osady ściekowe. Teoria i praktyka, Wydawnictwo Politechniki Częstochowskiej (2011)

12. A. Czechowska-Kosacka, Y. Cao, A. Pawłowski, Rocznik Ochrona Środowiska, 17, 337-350 (2015)

13. Eurostat, Sewage sludge production and disposal from urban wastewater (in dry substance (d.s)) (2015)

14. T. Pająk, INSTAL. Teoria i praktyka w instalacjach, 11 (2010)

15. C. Jakobsson, A. Gustafson, Sustainable Agriculture, Baltic University Press Uppsala (2012)

16. S. Smith, Encyclopedia of life support systems (2002)

17. M. Kacprzak, E. Neczaj, K. Fijałkowski, A. Grovelak, A. Grosser, M. Worwag, A. Rorat, H. Brattebo, A. Almas, B. Singh, Environ. Res. 156, 39-46 (2017)

18. G. Barberio, Environmental Engineering and Management, 12, 7-10 (2013)

19. T. Pająk, Environmental Protection Engineering, 39, 41-53 (2013)

20. Krajowy plan gospodarki odpadami (M.P. 2016 r., Nr 88, poz. 784) 